\title{
GELENEK VE MODERNIZM BAĞLAMINDA İSLAM
}

\author{
Ahmet Faruk KILIÇ* ve Sıddık AĞÇOBAN**
}

\section{Öz}

19.yy Avrupa aydınlanmasının bütün dünyada düşünce ve yaşam alanlarını etkilemesine modernizm adı verilmektedir. Modernizmin en temel özelliği bilimde akılcılığı, yaşamda ise din dışılığı (profan)esas almasıdır. Bu yaşam ve düşünce tarzının getirileri ilk olarak gelenek dediğimiz eski yaşam ve inanış şekillerini eleştiriye açtı. Bir süre kendini savunan geleneksel değerler birer birer yenilgi bayrağını çekince modernizmin başta kutsal algısına dayalı dini düşünceyi ve gelenekleri kaldırıp yerine kendi değerlerini yerleştireceği öngörülmeye başlandı. Ancak modernlik bütün çabalarına rağmen "kutsal"ı öldürmeyi başaramayınca geleneklerin birçoğu evrilerek yeni hayata uyum sağladı.

Değişime doğal olarak bir süre direnen İslam de medeniyeti modernizmin zorlayıcı tutumundan daha fazla müstağni kalamadı ve yeni dünya da kendine özgü yeni değerler üretme yoluna gitti. Modernleşmeyi Avrupalılaşmaktan ayırarak bir yandan özgün değerlerini korumak isterken diğer yandan çağa ayak uydurmanın yolarını aramaya başladı. İslam medeniyetinin "eski" ile "yeni"yi nasıl örtüştüreceğinin yollarını aradığı bu süreçte henüz yolun sonuna ulaştığı ve sonuçlar üzerinde fikir birliği sağlandığı söylenemez.

Anahtar Kelimeler: Gelenek, İslam, Din, Modernizm

\section{Islam In The Context Of Tradition And Modernism}

\begin{abstract}
19th century European enlightenment's affect the field of thought and life all over the world is named modernism. The main feature of modernism is that based on science the rationality, and on life the profane. Firstly yields of this new way of living led to criticism the form of ancient life and belief those are named tradition. Traditional values defended himself against the modernism. These values defeated one by one, was estimated that thought based on divine will be departured. And modern values will be settled in their place. However modernism although his effort, could not overcome the "divine". many of the traditions evolved and has adapted to new life.

For a while Islamic civilization naturally resisted the compelling change. But gave up from this and sought to creature unique values in the new world. Separating the modernization from the Europeanism on the one hand while trying to preserve the original values on the other hand started look for ways of keeping up with the times. Cannot be said yet the Islamic civilization in this process that wants to cherish "ancient" with "modernes" provided consensus on the discussion and reached the conclusion.
\end{abstract}

Key Words: Tradition, Islam, Religion, Modernism

* Doç. Dr., Sakarya Üniversitesi İlahiyat Fakültesi, Felsefe ve Din Bilimleri Bölümü Öğretim Üyesi (akilic@sakarya.edu.tr)

** Sakarya Üniversitesi İlahiyat Fakültesi, Din Sosyolojisi Bilim Dalı Yüksek Lisans öğrencisi (s.agcoban@hotmail.com) 


\section{Giriş}

19.yy. Avrupa aydınlanması ile başlayan süreç geleneksel yaşantıları şimdiye kadar hiç olmadığı ölçüde tartışmaya açtı. Aydınlanma ile birlikte gelen modern düşünce tarzı geleneksel düşünce ve yaşam biçimleriyle çatışma ortamına girdi. Bu süreç zarfında başta kutsal algısı olmak üzere geleneksel düşünce biçimlerinin giderek zayıflayacağı ve hatta tamamen yok olacağ1 öngörülmeye başlandı. 20. Yüzyılın sunduğu yaşam tarzı sonucu toplumlar gelenekten kopan bir ivmeyle değişmeye başlayınca modernizm, gelenek ve din kavramları sosyoloji disiplininin en popüler kavramları olmaya başladı. Modernlik ve gelenek üzerine yürütülen tartışmaların birçoğu, eski söylemlerin sıradan benzerleri olmasına rağmen bu konu uzun yıllar entelektüel tartışma dünyasının gündemindeki yerini korudu. Günümüzde de bu tartışmalar yeni boyutlarla genişlemiş olarak hala devam etmektedir.

$\mathrm{Bu}$ çalışmada konunun işleniş geleneğine uyularak gelenek, modernizm ve İslam olmak üzere üç kavram üzerinde yoğunlaşılmıştır. Bu bağlamda kavram tanımlarına yönelik açıklamalar hariç diğer kısımlarda genellikle Müslüman düşünürlerin görüşlerinden fazlaca yararlanılmıştır. Çalışmanın temasında, "gelenek ve modernizm çatışmasında İslamî düşünce gelinen son noktada hangi fikrî aşamadadır?" Sorusuna cevap aranmıştır. Bundan dolayı son dönemde yazılan kaynaklara geleneksel kaynaklardan daha fazla yer verilmeye gayret edilmiştir.

Batı modernizmi karşısında İslam geleneğinin durumu incelenirken genellikle "meydan okuma" kavramından yararlanılır. Buna göre İslamî gelenek modernizmin meydan okumasına maruz kalmış ve doğal olarak bazı direnç şekilleri geliştirme sürecine girmiştir. Eski yaşam ve düşünce şekillerinin olduğu gibi korunamayacağı anlaşılınca İslami geleneğin dönüşümü gündeme gelmiştir.

\section{Din, Gelenek Ve Modernizm Kavramları}

Din: Latincede "religio" sözüyle anlatılan din kavramı, "religere" veya "religare" kökünden gelmektedir. Religere kökünden, bir işi tekrar tekrar yapak anlamına gelir ve kişinin kendini ibadete vermesini anlatır. Religare kökünden ise bağlanmak anlamına gelir ve insanların din yoluyla tanrıya ve birbirlerine bağlanmalarını ifade eder. Öz Arapça' daki karşılı̆̆ı ise usul, adet ve tutulan yol demektir. ${ }^{1}$ Diğer bir ifadeyle kutsal fikrine dayalı olan ve müminleri bir sosyo-dinsel topluluk içinde birleştiren inançlar, semboller ve

1 Mehmet Taplamacioğlu, Din Sosyolojisi, Ankara: Ankara Üniversitesi İlahiyat Fakültesi Yay., 1961, s.36-37 
pratikler kümesidir. ${ }^{2}$ Din beşerî değil tanrı kaynaklı olan şeyler için kullanılır. ${ }^{3}$ Ancak tarifin daha kapsayıcı olması için Tanrı kelimesinin yerine "manevi varlıklar" terimini koymak gerekir. Bunun anlamı ise sıradan insanları aşan kuvvetlere sahip bilinçli varlılardır. ${ }^{4}$

Din her ne kadar tanrı veya kutsal kaynaklı şeyler için kullanılsa da her dinin belli sosyal şartlarda ortaya çıkması ve belli sosyal zümreler tarafından yaşatılmasi ${ }^{5}$ onu tamamen insani unsurlardan oluşan toplumun doğal parçası haline dönüştürmektedir. Toplumun bir parçası olarak din mefhumu o toplumun özelliklerinden müstağni kalamamakta adeta toplumla birlikte hareket etmektedir. Kültür seviyesinin yükselmesiyle doğru orantılı olarak dini akidede de görülen karmaşıklık (Hinduizm gibi) buna örnek olarak verilebilir. ${ }^{6}$ Gökalp de toplumu bir değerler armonisi olarak tanımlarken başına da dini koymakta7 böylece din kavramı ile toplum kavramının birbirinden bağımsız olmayacağını işaretlemektedir.

Gelenek (Tradition): Gelenek toplumda değerler ve kurumların en ağır değişen ve eski toplum devirlerini yenilerine bağlamaya yarayan sosyal miras olarak tanımlanmaktadır. ${ }^{8}$ Gelenek sözcüğünün Latince karşılığı olan “tradition" dağıtmak, yaymak, zaman içinde elden ele geçirmek anlamlarına gelen "tradere" sözcüğünden gelmektedir. ${ }^{9}$ Gelenekte önemli olan geçmişle olan bağlantıdır. Bu bağlantı hayali ya da gerçekçi olabilir. Toplumsal anlamda geleneksel toplum genellikle endüstriyel, kentleşmiş ve kapitalist modern topluma karşı kullanılır. ${ }^{10}$ Dini anlamda ise gelenek, medeniyeti ${ }^{11}$ vahye bağlayan zincirdir. Bu anlamda gelenek ne tarihi ne beşeri bir olgu-

2 Gordon Marshall, Sosyoloji Sözlüğ̈̈, çev. Osman Akınbay Derya Kömürcü, Ankara: Bilim ve Sanat Yay., 1999, s.156

3 Lort Nortbourne, Modern Dünyada Din, çev. Şehabettin Yalçın, İstanbul: İnsan Yay., 1995, s.11

4 Emile Durkheim, Dini Hayatın İlkel Şekilleri, çev. Fuat Aydın, İstanbul: Ataç Yay, 2005, s. 48,49

5 Joachim Wach, Din Sosyolojisine Giriş, çev. Battal İnandı, Ankara: Ankara Üniv. İlh. Fak. Yay., 1987, s. 33

6 Wach, Din Sosyolojisine Giriş, s. 34

7 Ahmet Faruk Kılıç, Ziya Gökalp'in Din Sosyolojisi, İstanbul: Değişim Yay., 2008, s.34-35

8 Hilmi Ziya Ülken, Sosyoloji Sözlü̈̆̈̈̈, İstanbul: MEB Talim ve Terbiye Dairesi Yay, 1969, s. 115

9 Robert Nisbet, "Gelenek ve Gelenekçilik”, Modern Toplumsal Düşünce Sözlü̈̆̈̈̈, Editör: William Authwaite, Haz. Melih Pekdemir, İstanbul: İletişim Yay., 2008, s. 300

10 Marshall, Sosyoloji Sözlü̈̆̈̈, s. 259

11 Yazar burada Hristiyan medeniyetini kastetmiştir. Yazarın ifadesinde doğruda Hristiyanlık geçmemektedir. Ancak yazar kitabın ilk bölümünde söyleyeceği şeylerin Hristiyanlık için geçerli olduğunu belirtmiştir. Bkz. Nortbourne, Modern Dünyada Din, s.11 
dur, onun kaynağı vahiy adını verdiğimiz doğrudan ilahi müdahaledir ${ }^{12}$ ve uzun bir geçmişi olan ve kutsallık halesi ile çevrelenmiş adetler için kullanılir. ${ }^{13}$

Gelenekle ilgili yapılan tanımlar ve gelenek üzerine geliştirilen düşünceler sınıflansa -geleneği tamamen reddetmek bir yana- bunların temelde iki anlam üzerinde şekillendiği görülür. Bunlardan biri gelenekten fikrî anlamda yararlanma ve değişen zamanla geleneğin özünü koruyarak yeniden üretmedir. İkincisi ise Kuran'da da yanlışlanan ${ }^{14}$ ve sırf atalara sadakat göstermek için yaşanan ve doğruluğu yanlışlı̆̆ı test edilmeden hayata taşınan, tabulaşmış ve kutsallaşmış gelenektir. Le Bon "Tapınaklarda geleneklerden daha heybetli putlar yoktur. Saraylarda geleneklerden daha güçlü hükümdar bulunmaz" derken geleneğin bu türüne işaret etmiştir. ${ }^{15}$

Gökalp geçmişi incelerken iki kavram üzerinde yoğunlaşır. Kural ve gelenek. Kural toplumun yapısına ve zamana göre sürekli değişen her toplumun kendine özgü ürettiği bir yaşam şeklidir. Kurallar toplumsal teamülün doğal bir sonucu olarak ortaya çıkar. Bir de toplumun geçmişi ile arasında anlamlı bir uyum kurmamıza yarayan gelenek vardır. Kurallar bizi geçmişe bağlarken gelenekler gelişmemizi sağlar. ${ }^{16}$ Buna göre toplumların geçmişle biri şekil bakımından diğeri anlam bakımından olmak üzere iki türlü bağlantısı vardır. Bu bağlantıyı şekil bakımından öne çıkarmaya ve savunmaya çalışmak, değişime karşı direnme konumunda geçmişe aynen bağlılığı ifade etmektedir. Bir de geçmişin dinamik yönünü teşkil eden bir anlam vardır ki geçmişte toplumun ürettiği değerleri modern dünyada tekrar üretmemize

12 Nortbourne, Modern Dünyada Din, s. 37. Cebeci de geleneklere bu anlamda yaklaşmıştır. Ona göre geleneklere önem vermek gerekir. Çünkü gelenekler dini inançlarla sıkı ilişki içindedirler. Dinlerin asırlar boyu yaşatılmasında geleneklerin önemli payı vardır. Hatta değerler ve kültürleri yaşatma, bunları gelecek nesillere aktarma konusunda eğitimle aynı görevi görmektedir. İslam'ın öne çıkardığı değerlere uygun davranışların sosyal gerçeklik içerisinde kalıcılığ gelenekle bağlantılıdır. Gelenek toplumsal kararlılığın ve meşruluğun kaynağı olarak da görülür. Gelenekler yazılmamış kanunlardır. Ve yazılmış kanunlardan daha güçlü daha bağlayıcı ve daha saygındır. Şu var ki değişmeyen dini esaslar, yaşantılar ve hükümler kalıcı yaşantılara dönüşmedikçe "inne lillahi" düsturunun bütün sosyal ve bireysel yaşantılarda ideal bir ölçü olarak gerçekleşmesi mümkün olmayacaktır. İslam akidesin de de amellerin en hayırlı olanı devamlı olanıdır. Bkz. Suat Cebeci "Din Eğitim Açısından Dinî Yaşantıların Gelenekleştirilmesi", Harran Üniversitesi İlahiyat Fakültesi Dergisi, 1996, Sayı:2, s. 75-81

13 Modern Toplumsal Düşünce Sözlüğ̈̈̈, s.300

14 Onlara: "Allah'ın indirdiğine ve elçiye gelin" denildiğinde, "Atalarımızı üzerinde bulduğumuz şey bize yeter" derler. (Peki,) Ya ataları bir şey bilmiyor ve hidayete ermiyor idilerse? (el-Maide 5/104)

15 Gustave Le Bon, Kitleler Psikolojisi, İstanbul: Siyaset Hayat Yayınları, 1997, s. 76

16 Ziya Gökalp, Türkleşmek, İslamlaşmak, Çağdaşlaşmak ve Doğru Yol, Haz. Yusuf Çotuksöken, İstanbul: İnkılap ve Aka Yay., 1976, s. 34-38 
yarayacak bağdır. Gökalp’e göre biz geçmişe bu ikinci bağla bağlanmalıyız. 17

Gökalp örf, anane, teamül gibi kavramları anlam bakımından sınıflarken “örf" ü diğerlerinden ayırmış ve geleneğe yakın anlamda kullanmıştır. Âdet, anane, teamül gibi kavramlar geçmişe şekil bakımından bağlılığı ifade ederken "örf" cemiyetlerin her asırda gelişiminin ana dinamiğini oluşturan anlamı ifade etmektedir. Ona göre örfün gerçek manası Kuran'da da verilmiştir. Kuran "innâ vecadnâ êbâenê" (el-Maide 5/104) diyenleri yani anane ve âdetlere teamüllere kıymet verenleri takbih ettiği halde "örfü emrediniz, marufu emr, münkeri nehyediniz" buyuruyor. Örf, teamül veya âdet değildir. Cemiyetler gelişirken gelişimin her safhasında belirli bir örfe tabi bulunmak mecburiyetindedirler. ${ }^{18}$

Mustafa Armağan ise geleneği dörde ayırır. Birincisi: Zaman üstü bir bilgelik olarak gelenek: bu dinin özünden gelen ve medeniyetlere ilham veren ezeli/ebedi hikmettir. İkincisi: kurumlaşmış bir otorite olarak gelenek. Üçüncüsü: adet örf ve görenek (sosyolojik gelenek) dördüncüsü: geçmişten bir fikri araç olarak yararlanma (Araçsal gelenek). ${ }^{19}$ Bu tasnif Gökalp'in sınıflaması içerisinde tekrar ele alınsa birincisi ve dördüncüsünün, gelenek ve örf; ikincisi ve üçüncüsünün ise kural ve adet olarak karşılı̆̆ını bulduğunu söyleyebiliriz.

Gelenek kavramını günümüzde ateşli tartışmaların ortasına atan durum modernlik kavramının etrafını çizerken yaşanan sıkıntılardır. Modernizmin geleneğin yaşamasına izin verip vermeyeceği, verse bile ne kadarına izin vereceği sosyolojik anlamda son dönemin en popüler söylemlerine konu olmuştur. Bakıldığı zaman bu söylemlerde gelenek ve moderniz kavramlarının sürekli beraber kullanıldığı, birinin anlamını belirlenirken diğerinden sıkça yararlanıldığı görülür. Şimdi de modernizm ve onun eskiye daha sıcak bakan halini ifade eden postmodernizm kavramlarına kısaca değinelim.

17 Gökalp, Türkleşmek, İslamlaşmak, Çağdaşlaşmak ve Doğru Yol, S.34-38. Gökalp'e göre Türk milleti olarak biz gelenek bakımından zayıf ve fakat kural bakımından güçlü durumdayız. İngilizler ise gelenek bakımından güçlü kural bakımından zayıf durumdadırlar. İngilizlerin gelişmesini sağlayan da gelenekleridir. Bkz. Aynı yer.

18 Kılıç, Ziya Gökalp'in Din Sosyolojisi, s. 128-131

19 Mustafa Armağan, Gelenek ve Modernlik Arasinda, İstanbul: İnsan Yay., 1995, s. 64-67. Armağana göre Seyyid Hüseyin Nasr birinci kısmın temsilcisidir. Nasr 'a göre -daha sonra da geleceği gibi- iyi bir gelecek inşa etmek istiyorsak gelenekte ne varsa aynen taşınmalıdır, Şeriati, Fazlurrahman ve Abdullah Laroui ikinci kısım geleneğin temsilcileri konumundadır. Bunlara göre gelenek çözecek şeyleri çözmüştür. Geleneksel yorumların tekrarlanıp durulmasından ziyade günümüz ihtiyaçlarına yeni bir ihtiyaç perspektifinin gerekliliği gündeme gelmiştir. Bkz. Aynı yer. 
Modernizm ve Postmodernizm: Modernizm kelimesi eski Latincedeki "modernus" kelimesinden alınmıştır. Bu kelime de "modo" dan türetilmiştir. Modo ise hemen şimdi anlamına gelir. Bu bakımdan modernleşme eski zamanların toplum tipinden günümüzdeki toplum tipine doğru bir gelişme demektir. ${ }^{20}$ Modernizm genelde 19. yy sonu ile II. Dünya savaşının başlang1cına kadar olan dönemde büyük çaplı değişimleri tanımlamakta kullanılan bir terimdir. Belli bir bitişi ise yoktur. ${ }^{21}$ Aktay'a göre modernizm kavramı günümüz şartlarında toplumsal durumları yorumlamak için yetersiz kalmaktadır. Modernlik kavramının aslında tarihsel ve toplumsal kökleri ortaya çıkmış bir kavram olmasına rağmen her şeyi içine alan geniş bir realiteyi taşıması düşünülemez. Modernlik kavramı altındaki çeşitlilik ve farklılaşmaları anlatmak için alt kavramlar ve ara kategorilere ihtiyaç vardır. ${ }^{22}$ Buna göre aslında Avrupa'nın yaşam evrimlerine göre türetilmiş ve anlamı genellikle başkaları tarafından konulmuş modernizm, İslam dininin toplumsal anlamda evrildiği süreçleri tanımlamakta yetersiz kalmaktadır. Yaşanan süreçlerini tanımlamakta çekilen sıkıntı ve yetersizlik de ileriye dönük öngörüleri kaypak bir zemine oturtur. Öyleyse modernlik adına İslam toplumlarında çözüm bekleyen problemler varsa ilk çözüm denemeleri kavramlar üzerinde yapılan çalışmalarla başlamalıdır.

"Karşıtlık" kavramı, modernizm ile gelenek beraber ele alınırken ilişki türünü belirlemek için kullanılan kavramlardan birisidir. Buna göre modernizm ortaya çıkmaya başladığı andan itibaren geleneğe savaş açmış gelenek ise bu savaşa karşı direnmiştir. Modern geleneksel karşıtlığında en temel argüman ise kutsal algısındaki değişme olmuştur. Meriç'e göre modern alg1da yaratan (kutsal) dinlenen konumdayken asıl faal olan insandır. ${ }^{23} \mathrm{Bu}$ nunla birlikte modern algida yaratan (kutsal) dinlenen konumda olmaktan bile çıkarılarak tamamen yok olacağı düşüncesi de mevcuttur. Nitekim Özay'ın kurucu sosyologlar diye kastettiği Auguste Comte, Emile Durkheim, Max Weber, Karl Marx gibi ilk sosyologlar dinin rasyonel düşüncenin eşlik ettiği endüstrileşmenin geleneksel toplumlardaki tanrıların yerini almasıyla önemini yitireceğini öngörmüşlerdir. ${ }^{24}$

Armağan ise, geleneğin aslında modern düşünce literatüründe kendini savunmaya başladığı andan itibaren gelenek olmaktan çıktığını ve muhteva açısından modern düşüncenin bir parçası olduğunu savunarak geleneği

20 Emre Kongar, Toplumsal Değişme, Ankara: Bilgi Yay., 1972, s. 194

21 Marshall, Sosyoloji Sözlüğ̈̈, s. 508

22 Yasin Aktay, "Modernleşme ve Gelenek Bağlamında Dini Bilgi ve Otoritenin Dönüşümü", Bilimname VI, 2004/3, s.137,138

23 Nevin Meriç, Değişen Kentte Dini Hayat, İstanbul: Kapı Yay., 2005, s.343,344

24 Mehmet Özay, Sekülerleşme ve Din, İstanbul: İz Yay., 2007, s. 43 
modern algının muhtevasına dönüştürmüş ve adeta ezeli rakip bu iki kavramı barıştırmayı denemiştir. ${ }^{25}$ Şu var ki bu ve buna benzer barıştırma denemeleri gerçek hayatta verimli bir zeminde karşılık bulmayı başarmıştır. Yani modernizm ve gelenek karşıtlığı gelinen son noktada yumuşayarak ortak değerler üzerinde adeta anlaşma masasına oturmuştur. Bu anlaşma sürecinin sosyolojik düşüncedeki karşılığı literatüre postmodernizm denilen yeni bir kavram kazandırmıştır.

Postmodernizm kavram olarak 1950 ve 1960 yıllarında ve ilk olarak mimaride kullanılmaya başlamıştır. Ancak zamanla bütün değişim alanlarını kapsayacak şekilde genişlemiştir. ${ }^{26}$ Kavramın Türkçe karşılı̆̆ 1 modernizm ötesi demektir. Modernizmi merkeze alan bu deyim "öte" veya "sonra" sözcükleriyle tam doğrusal olmasa da yine de belli bir gelişme çizgisine atıf yapar. Bu hareket batıda çıkan aydınlanmacı felsefeye ve bizzat modernizme yöneltilmiş bir eleştiridir. ${ }^{27}$

Armağan, müslüman aydınların düşünsel alanlarını gelenek-modernizm tartışmasından postmodernizm üzerine kaydırdığına dikkat çekmektedir. Ona göre ümitler postmodernizmin geleneği de kurtaracak bir can simidi olduğu üzerinde tekrar canlanmıştır. Öteki ifadesiyle postmodernliğin, modernliği köşeye sıkıştırıp dine ve geleneğe göz kırpması modernliğin kâbusundan yeni uyanmış aydınımızı yeni bir müttefik bulmanın ümidiyle sevindiriştir. ${ }^{28}$ Ancak Bulaç’a göre bu sevinç müslümanlar açısından gereksizdir. Çünkü postmodernistler en başta hakikatin birliği fikrini reddediyorlar. Bir açıdan tevhidi inkâr edip şirkin kurumsallaşmasını öngörüyorlar. Böyle olunca tek bir tanrı yoksa birden fazla tanrı vardır ve bir andan insanın kafasının içi gibi hayatı da paganist bir arenaya döner. Postmodernizmin İslami açıdan bir handikabı daha vardır. Bu söylem insanı ve evreni epistemolojik ve ahlaki içeriğinden, ilahi, kutsal ve aşkın amacından koparma, ontolojiye içkin yeni bir kargaşa tasarımını ön plana çıkarma fikrine dayanmaktadır. Her ne kadar Shumacher gibi yazarlar insanoğlunun tek kurtuluş çaresinin bu günkü modernizmden dine dönüşünde olduğunu söyleyip bunu postmodern zamanın en belirgin ve kesin olgusu olduğunu söylüyorlarsa bile biz yine de özünde doğrusal tarih görünüşünü barındıran böyle bir gelişmeye sahici bir umut bağlayamayız. ${ }^{29}$

Yukarıda geçen ve postmodernizm hakikatin birliğini kabul etmeye yanaşmamasını Armağan daha genel bir ifade ile şöyle anlatmaktadır. Mo-

25 Armağan, Gelenek Ve Modernlik Arasında, s. 13,14

26 Tony Pinkney, “Modernizm ve Postmodernizm”, Modern Toplumsal Düşünce Sözlüğü, s. 504

27 Ali Bulaç, Din ve Modernizm, İstanbul: Yeni Akademi Yay., 2006, s. 179-181

28 Armağan, Gelenek ve Modernlik Arasında, s. 35-37

29 Bulaç, Din ve Modernizm, s. 185-187 
dernlik gelenekten muhteva açısından koparken onu biçim açısından devam ettirmiştir. Postmodernlik ise gelenekten biçim açısından koparken muhteva açısından sürekliliği ifade etmiştir. ${ }^{30}$ Mesela modernizm geleneksel bir düşünce olan tanrı inancı ile çatışırken onu yenemediği alanlarda "gelenek" kavramının içine hapsederek kenarda bırakıyordu. Ama postmodernizm geleneğin muhtevasını oluşturan tanrı inancını korurken onu biçim bakımından değiştirmeye mesela "tanrı" yerine "tanrılar" kavramını koymaya çalışıyor. Başka bir örnek verecek olursak; ABD'de kadın imamın erkeklere namaz kıldırması, kadın erkek karışık namaz, Pakistan'dan imam olarak yetiştirilmek üzere ABD' ye gönderilen kişiler, ${ }^{31}$ postmodernizmin geleneğin biçimini değiştirip ve fakat muhtevasını korumasına örnek olarak verilebilir.

Modernleşme ve Batılılaşma: Sosyolojik analizdeki ilk girişimler Avrupa'yı saran iki büyük değişim dalgasını -sanayileşme ve Amerikan ve Fransız Devrimlerinin arkasından gelen demokrasi ve insan haklarının genişlemesi- açıklama gerekliliğinden kaynaklanmıştır. ${ }^{32} \mathrm{Bu}$ gereklilikten doğan açıklama çabaları düşünce ibrelerini Avrupa'nın dışına çevirdiği zaman cevaplanması gereken başka problemler olduğunu fark etmiştir. En başından doğu toplumlarının geçirdiği veya geçireceği değişim evreleri Avrupa'nınki ile aynı mı olacaktır, Avrupa'nın değişimini anlatmak için getirilen kavramlar diğer toplumları anlatmak için yeterli olacak mı? Vs. bundan dolayı gerek ilgili kavramlara yönelik yapılan tanımlar gerekse konu üzerine geliştirilen söylemler konuyu zaman zaman, modernleşmek demek Avrupalılaşmak demek mi? sorusu bağlamında ayrı bir düzleme taşımıştır. Buna gerekçe olarak modernleşme olgusunu başlatan unsurların Avrupa kaynaklı olması gösterilebilir. Nitekim aşağıda da geleceği gibi ilk olarak batılı düşünce içinde geliştirilen söylem ve argümanlar bütün toplumların modernleşme ve buna bağlı olarak medenileşmede başarılı olmak için Avrupa'nın geçtiği değişim evrelerini aynen geçmesi yani bir nevi Avrupalılaşması gerektiğini öngörüyordu. Bu evreleri geçmeyenleri ise doğulu ve geleneksel diyerek dişliyordu.

Bu ayrıma ilk olarak K. Marx ve M. Weber'in düşünce sistemleri içerisinde rastlamak mümkündür. Zira bu düşünce sistemlerinde genellikle doğu toplumları mekanla, batı toplumları ise zamanla ilgili terimlerle ifade edilmiştir. Böylece Batıda gelişmenin Doğuda ise durağanlığın hakim olduğuna dair fikren zemin hazırlamaktadırlar. Her ikisi de Hegel tarafından dile getirilen ve yaygın bir kabul gören anlayışla doğuya durağanlık, batıya ise di-

30 Armağan, Gelenek ve Modernlik Arasında, s. 78

31 Meriç, Değişen Kentte Dini Hayat, s. 343,346

32 Marshall, Sosyoloji Sözlüğ̈̈, s. 136 
namizm atfetmektedirler. ${ }^{33}$ Yine başta Edward Said olmak üzere Batılı düşünce ve sanat adamlarının Doğuyu oryantal yani değişmez, durağan, erotik, otoriter olarak Batıyı ise dinamik yenilikçi, rasyonel ve hoşgörülü olarak sınıflandırdıkları görülmektedir. ${ }^{34}$ Yine Eisenstadt modernleşmeyi tarihsel olarak batı Avrupa'da ve kuzey Amerika'da geliştirilmiş olan toplumsal ekonomik ve sosyal sistemlere doğru bir değişim yönü olarak tanımlamıştır. Larner ise buna modernleşme konusunda Batı modelinin evrensel olarak geçerli olduğunu ileri sürerek ek yapmıştır. ${ }^{35}$ Ancak bu tarz bir düşünme şekli başta modern sosyolojinin temel varsayımları ile çelişmektedir. Zira toplumsal bilimlerde öze uygun olan toplumların değişmesidir. Bu nedenle toplumları statik ve dinamik olarak sınıflandırmak suni bir ayrımdır ve gerçeği yansıtmamaktadır. Bunun için de zamanımızın sosyal bilimcileri tarafından reddedilmektedir. ${ }^{36}$ Gökalp, "hayatın lübbü velud bir tekamüldür" 37 diyerek toplumlardaki bu dinamik öze dikkat çekmiştir.

Batıda gelişen bu düşünce tarzına karşı bir tepki literatürü oluşturduğu anlaşılan İslami düşüncede modernizme her anlamda karşı çıkılmaz. Gelinen son noktada Müslüman toplumların modernleşmeyi kabul etmekle birlikte koşulsuz Avrupalılaşmak yerine kendine özgü bir modernite üretme arayışına girdiğini söyleyebiliriz. Modernleşmek ile medenileşmeyi bir birinden ayıran Şeriati, medeniyetin modernlik olmadığını şu anki modernliğin Avrupalılaşma ve Avrupalı gibi yaşama anlamında bir nevi asimilasyon olduğunu belirtmiştir. Ona göre ne yazık ki modernizm biz Avrupalı olmayan toplumlara medeniyet adı altında empoze edilmiştir. ${ }^{38}$ Şeiati'ye göre gerçek medeniyet ruhsal bir olay manevi ve fikri bir yükselme, her yeteneğin onda açılıp gelişebileceği elverişli bir ortamdır. ${ }^{39}$ İkbal de Avrupa'nın gelişiminin Avrupa'yı dinsizliğe dini şüpheciliğe ve ekonomik anlaşmazlı̆̆a sürüklediğini belirterek İslam coğrafyasının kendi derdinin çözümünü kendisi üretmesi gerektiğini ifade etmiştir. Ona göre "Kabe'nin hayat örtüsü İslam, Batı'dan Lat ve Menat putlarının getirilmesi ile ihya olmaz." 40 Çapç1oğlu'na göre de batılı olmayan ülkelerin kendi dinamikleri ile kendilerine özgü modernleşme tipi üretmeleri mümkündür. Buna göre mesela Türki-

33 Lütfi Sunar, Marx ve Weber'de Doğu Toplumları, İstanbul: Ayrıntı Yay, 2012, s. 235

34 İhsan Çapçıŏlu, Küreselleşme Kültür ve Din, Ankara: Otto Yay., 2011, s. 260

35 Kongar, Toplumsal Değişme, s. 193

36 Kongar, Toplumsal Değişme, s. 218,219

37 Gökalp, Türkleşmek, İslamlaşmak, Çă̆daşlaşmak Ve Doğru Yol, s.35

38 Ali Şeriati, Medeniyet ve Modernizm, çev. Ahmet Yüksekoğlu, İstanbul: Bir Yay., 1985, s. 7-8

39 Şeriati, Medeniyet ve Modernizm, s. 37

40 Latif Ahmed Sirvani, İkbal'in Konuşma ve Yazıları, çev. Can Ceylan, İstanbul: İnkılap Yay., 2011, s. 319 
ye'nin kendine özgü bir "iç modernite" kavramının varlığ1 mümkün hata zorunludur. ${ }^{41}$

\section{İslam, Gelenek ve Modernleşme}

19. yy.'da Avrupa'nın yaşadığı köklü değişim şimdi adına modernizm dediğimiz yaşam biçimini oluşturmaya başlayınca, dinin bu değişimden nasıl etkileneceği gündeme geldi. Bu değişimin gidiş yönü dini değerlere ve geleneksel yaşam tarzına karşı topyekûn meydan okuma şeklinde gelişmeye başladı. Geleneksel dini yaşam ve düşünce tarzı, Avrupa'da modernizmin takdim ettiği profan (din dışı) yaşam tarzı karşısında güç kaybına uğrayınca dinin geleceği hakkında ileri sürülen öngörüler giderek netleşti. Başta Auguste Comte, Emile Durkheim, Max Weber, Karl Marx gibi sosyologlar dinin rasyonel düşüncenin eşlik ettiği endüstrileşmenin geleneksel toplumlardaki tanrıların yerini almasıyla önemini yitireceğini öngördüler. ${ }^{42}$ Durkheim'e göre din, bilimin ve genel olarak açık düşüncenin sınırları dışında kalan her şey hakkında bir tür spekülasyondan ibaret olan bir şeydi. ${ }^{43} \mathrm{Bu}$ haliyle bilimsel bilginin her alanı dolduracak kadar gelişmesi durumunda dinin ortadan kalkacağı mantıken kabul edilmiş oluyordu.

Ancak günümüzde gelinen nokta, kurucu sosyologların din hakkındaki öngörülerinin yeniden gözden geçirilmesi gerektiğini göstermiştir. Son asırda yaşanan olağanüstü akli ilerleme ve toplumsal değişimlere rağmen din ve buna bağlı kutsal kavramı insan hayatındaki yerini korumaya devam etmiş hatta -ilerde geleceği gibi- giderek artan bir ivme ile canlılık kazanmıştır. Bundan dolayı son durumda din ve kutsal üzerine düşünen sosyologlar eskilerin söylem ağzını değiştirmeye başladılar. Buna göre din sahip olduğu ilk saflık ve mükemmellikten zaman geçtikçe kaçınılmaz olarak uzaklaşır. Ancak bu uzaklaşma ölme veya yok olma değildir. Dinin hayati kıvılcımı hiçbir zaman sönmez. ${ }^{44}$ Yani böylece eskilerin "bitiş" diye öngördükleri durum aslında bir değişim ve uyum sürecinden ibaret olmaktadır. Öyleyse Hans-George Gadamer "en köklü devrimlerde bile sanılanın aksine eskiye ait çok fazla unsur muhafaza edilir" 45 dini değerlerin hala hayatımızda önemli olduğuna işaret etmiştir.

41 Çapçığlu, Küreselleşme Kültür Ve Din, s. 269

42 Mehmet Özay, Sekülerleşme ve din, İstanbul: iz yay., 2007, s. 43. Özay, bu çalışmasında kutsal kavramıla tanrı kavramı arasında net bir ayırım yap(a)mamış birini diğerinin yerine kullandığı olmuştur. Halbuki başta da geçtiği gibi iki kavram arasındaki fark vardır. Buna göre her kutsal tanrı olmamaktadır.

43 Emile Durkheim, Dini Hayatın İlkel Şekilleri, çev. Fuat Aydın, İstanbul: Ataç Yay., 2005, s. 43

44 Nortbourne, Modern Dünyada Din, s. 77,78

45 Armağan, Gelenek Ve Modernlik Arasında, s. 35 ayrıca bkz: Ülken, Sosyoloji Sözlügü, s.115 
Görünen o ki, modernizmin profan yaşamı alabildiğine önceleyen tutumuna rağmen başta dini yaşam olmak üzere gelenekler yeni hayat tarzına uyum sağlayacak şekilde evrilmeye başladı. Daha önce de bahsi geçtiği gibi geleneğin özünü temsil eden dinamik güç (Gökalp'e göre örf) eski yaşam şekillerinin yıkılmasına aldırmadan onun yerine yeni değerler üretmeye başladı. Kağıtbaşı'nın sanayileşmeye karşın devam edebileceğini belirttiği bu güç46 aslında modern dünyanın da büyük bir coşkuyla sahip çıktığ1 değerlerin mukaddimesini de içinde yaşatmaktaydı. Mesela modern dünyanın en popüler fikirleri olan hümanizm, akılcılık, eşitlik, serbest düşünce gibi akımlar bile Nortbourne'e göre aslında geleneksel Hristiyan düşüncesinde din dişılığı temsil etse bile şu veya bu biçimde her zaman var olmuştur. Yeni olan bu düşüncelerin dünya çapına yayılmış ve düşünce alanlarını etkisi altına almış olmasıdır. ${ }^{47}$

Modernleşmenin toplumsal olayları yorumlarken kullanıma sunduğu kavramlardan biri de "sekülerleşme"dir. Genel kabule göre sekülerleşme modernleşmenin zorunlu sonucu olarak ortaya çıkmıştır. Bazıları sekülerleşmeyi bir işgal ve hatta kültürel tecavüz şeklinde şeytani bir unsur olarak değerlendirmektedir. Bu anlamdaki sekülerleşme aynı zamanda dinin kamusal alanda dişlanmasına yönelik bir manivela olarak algılanmaktadır. ${ }^{48}$ Klasik din sosyologları, sekülerleşmeyi metafizikten 'arınma' süreci olarak görüyorlardı. Ama aslında gelinen son nokta, sekülerleşmenin bir geleneğin dönüşümü olduğunu göstermeye başladı. Farklı kültürler, farklı örfler ve farklı dini gelenekler modern zamanlarda kendilerine özel sekülerleşme biçimleri ürettiler. ${ }^{49}$ Özay'a göre de sekülerleşme yeni dini hareketlerin ortaya çıkmasına yaradığı gibi din olgusuyla birbirilerini etkileyen diyalojik bir etki içine girmiştir. İnsanlar gerek bireysel gerekse cemaat boyutunda kutsalla ilişkilerini sürdürmektedirler. Bireyler modern dünyada dini yönelimlerini öz dönüşümsellik yöntemiyle bizzat kendileri üstlenmiştir. Böylece kurucu sosyologlar ve bazı sosyal bilimcilerin dinin geleceğine dair biçtikleri karamsar tablo gerçekleşmemiştir. ${ }^{50}$

Modernleşmenin kutsal algısına dayalı geleneği bitiremeyişi kutsalın yeni bir formla tekrar yaşam alanına dönüşünü gündeme getirdi. Bu bir nevi kutsalın zaferiydi. Ama dini geleneğin modern zamanın getirileri karşısında nasıl bir duruş sergileyeceği, eskiyi ne kadar koruyacağı veya yeniyi ne ka-

46 Çiğdem Kağıtçıaş̧ı, İnsan ve İnsanlar, İstanbul: Beta Basım Yayım, 1985, s. 281

47 Nortbourne, Modern Dünyada Din, s. 21,22

48 Çapçıŏlu, Küreselleşme Kültür ve Din, s. 269

49 Mehmet Görmez, "Bir Şeyler Yaparken Bütün Dünyayı Hesaba Katmalıyı", Zaman:09.01.2012

50 Özay, Sekülerleşme ve Din, s. 258 
dar kabulleneceği konusundaki belirsizlik sosyal bilimcileri yeni bir düşüncenin ufkuna taşıdı. Modern zamanda din ve gelenek hangi şartlarda yaşayabilir, hangi koşullarda hayata uyarlanırsa çağdaş problemlerin çözümüne ayak uydurabilirdi? Bilhassa son ilahi mesajın evrensel öğretisini gelecek nesillere aktarma ve dünya çapına yayma arzusuyla bütünleşen İslam dini, aydınlarını konu üzerinde yüzlerce yıl sürecek bir düşünce platformuna sürükledi.

Eski kuşaklarda aktarılan kültürel mirasın yeni dünyada nasıl işleneceği sorunu, oluşturduğu düşünce yelpazesinde gelenekçilik denilen bir tarzın oluşmasına yol açtı. Gelenekçilik "kültürün eski kuşaklardan miras olarak aldığı kısımlara dayanmak ve toplumda değişmelerin doğuracağı sarsıntılara karşı böylece direnmek fikrini savunan görüş" anlamına gelmektedir. ${ }^{51}$ Sosyolojideki gelenekçiliğin İslam mezhepler tarihinde "Selefilik" denilen düşünce tarzıyla örtüştüğü söylenebilir. Cemaleddin Afgani, Muhammed Abduh, Muhammed İkbal, Mehmet Akif Ersoy gibi batıyı iyi bilen, akla, ilme ve teknik gelişmelere önem veren Müslüman alimler Selefiliğin (Ortodoks İslam) bir bakıma günümüzdeki temsilcileridir. Selefiliğe göre en iyi din sahabe ve Hz. peygamber başta olmak üzere ilklerin yaşadığı dindi. O yaşam tarzının ve düşünce biçimimin dışına çıkmak dinin dışına çıkmaktı. ${ }^{52}$

Seyyid Hüseyin Nasr'ı Ortodoks İslam'ın temel yaşam tarzı ve öğretilerini günümüze aynen taşıma kaygısıyla hareket eden gelenekçi düşüncenin temsilcilerinden biri olarak sayabiliriz. Nasr geleneğe tam manasıyla sahip çıkabilirsek her türlü problemimizi çözebileceğimizi düşünmektedir. Ona göre gelenek adına ne varsa ona sahip çıkmalı modernizmin bütün getiri ve şartlarını ise reddetmeliyiz. Modern demek aşkından yani gerçekte her şeyi idare eden en genel anlamıyla vahiy ile insana bildirilen değişmez "müteal" ilkelerden kopmuş olan şey demektir. Bu anlamda modernizm geleneğin zıddıdır. Din ilahi olanı modernizm ise beşeri ve beşer altı olanı ima eder. ${ }^{53}$

Ancak Nasr'ın klasik selefi düşünceden ayrıldığı bir nokta vardır. Nasr batı modernizmine karşı çakan bütün İslami akımları bir hamlede "fundamentalist" diye silip kenara atarken sadece kendisinin temsil ettiği gelenekçi akımın meşru olduğunu ileri sürmektedir. Bu akımın temel dayanağ1 ise zengin kültürel, bilimsel mirasa sahip İslam mirasına Tasavvuf ve Şia öğretisini esas alarak sahip çıkmaktır. Nasr'a göre modernizme karşı sahih sünnet ve Kur'anla doğrulanan gelenekle değil ne olursa olsun yaşanmış ve tecrübe edilmiş gelenekle karşı çıkılmalıdır. Nitekim onun düşünce dünyası şu

51 Ülken, Sosyoloji Sözlüğ̈̈̈, s. 115

52 Süleyman Uludağ, İslam Düşüncesinin Yapısı (Selef, Kelam, Tasavvuf, Felsefe), İstanbul: Dergah Yayınları, 2010, s. 29-36

53 Seyyid Hüseyin Nasr, Makaleler:1, çev. Şehabeddin Yalçın, İstanbul: İnsan Yay., 1995, s. 74 
prensibe dayanır: Tarihte ne olduysa gelenek adına olduğundan meşru ve doğrudur. Buna benzer bir Yahudi öğretisi vardır "eğer gelenekse doğrudur". 54

Nasr'ın temsil ettiği gelenekçi düşüncenin modern zamanın bütün getirilerinin her ne şekilde olursa olsun yaşanmış geleneğe uyarlanmasını öngören tutumunun tam tersi diyebileceğimiz bir düşünce tarzı daha vardır ki bunun temsilciliğini Fazlurrahman'ın yaptı̆̆ı söylenebilir. ${ }^{55} \mathrm{Bu}$ düşünce tarzına göre modernizmin getirdiği yaşam tarzını Kur'an ve sünnetle bütünleştirmek mümkündür. İslam'a bağlılık kaybolmazsa modern sekülerizmin müslüman toplumlar tarafından özümsenmiş bütün içeriği İslam'1n hakikat kaynaklarına -Kur'an ve Sünnet'e- canlı şekilde bütünleştirilebilir. ${ }^{56}$ Biraz daha detaylandıracak olursak, Fazlurrahman Kur'an'1 modern dünyada İslam'dan üretilebilecek olan bir değerler sisteminin kaynağı olarak görüyor, karşılaşılacak problemlerin çözümü için de bir metod olarak Mekke-Medine dönemlerinin tarihsel ufuklarıyla şimdiki zamanın tarihsel ufku arasında hermönetik bir yolculuğun yeterince faydalı olacağına inanıyordu. Mesela Kuran'ın ceza hukukuna yönelik hükümleri Fazlurrahman'a göre Kur'an tarafından baştan vazedilmiş ve mutlak geçerli olan hükümler değil o dönemde Arap toplumlarının zaten uyguladığı hükümlerdi. Kuran bunların içinde o dönemin ruhuna en uygun olanı seçip önermişti. Günümüzde yine mesela ceza hukukunda yaşadığımız dünyanın ruhuna en uygun hükümleri

54 Bulaç, Din ve Modernizm, s. 225; Ayrıca bkz. Armağan, Gelenek ve Modernlik Arasında, s. 63

55 Ali Şeriati'yi düşünce tarzı bakımından Fazlurrahman'ın temsil ettiği ekole yakın sayabiliriz. Nitekim Şeriati'ye göre modern dünyada geleneğin değişmesi ve onun yerine modern bir nosyon olan ideolojinin geçmesi gerekmektedir. (Bkz. Armağan, Gelenek ve Modernlik Arasında, s. 63) ve fakat Şeriati, dini referanslara çokça müracaat etmesinin sebebini soranlara "Bizim dine dayanış ve sarılışımız geçmişe dönüş anlamında değil aksine tarih sürecini sürdürmek anlamındadır" cevabını vererek Nasr'ın sürdürdüğü geleneğe tamamen zıt olmadığını işaretlemiştir. Bkz. Ali Şeriati, Dine Karşı Din, çev. Hüseyin Hatemi, İstanbul: İşaret yay., 1987, s. 49

Modern Düşüncenin Geleneksel Eleştirisi: Akıl ve sağduyunun yanında bir de nefis ve heva vardır. Bunlar serkeşlikten ve serserilikten hoşlanır. Nefsinin sesine kulak verenler yaşadığı serkeşliği serüven olarak algılamaya başlar. Yaşadığı manevi sıkıntılardan kurtulma çabasını ise değişim ve gelişim olarak adlandırır. Bunu anlatmak için de aydınlanma, modernleşme, ilerleme ve çağdaşlaşma gibi kavramları kullanır. Halbuki bu değişimin (!) mümessilleri dini düşüncenin ana çerçevesini temsil eden "tüm zamanlar için geçerlilik" prensibinden haberdar olsalardı ve bunun üzerine biraz kafa yorsalardı problemler daha başlamadan çözülürdü. Bkz. Salim Öğüt, Modern Düşüncenin Kur'an Anlayışı, İstanbul: Nun Yay., 2008, s.287,288. Tarihsellik tezini ortaya süren aydınların emeli vahiy kültürünü modern ve seküler dünyanın kabulleriyle uyumlu hale getirmektir. Çünkü bunlar modern ve seküler dünyanın kabullerini vahiy kültürüne evirmeyi başaramamışlardır. Aynı yer, s. 114

56 Fazlurrahman, İslami Yenilenme, (Makaleler:3), çev. Adil Çiftçi, Ankara: Ankara Okulu Yay., 2002, s. 86 
seçebiliriz. Bu şekilde davranmakla kuranın ruhuna aykırı düşmüş olmay1z. ${ }^{57}$

Geçmişi sınıflandırırken tarihi İslam ile kuralsal İslam arasında kesin bir ayırım yapan ${ }^{58}$ Fazlurrahman'a göre müslümanların atması gereken en önemli ilk adım eski ve yeni meselelerin kaynaştırılıp mezcedilmesidir. Bunların şeklen yan yana getirilmesi ile üretken İslami kafa geliştirilemez. ${ }^{59}$ İkinci adım ise sorunları derinlemesine çözmeyi denemektir. Ona göre aslında modernistlerin önündeki ana sorun toplumu İslami bir çerçeve gerçekten değiştirmeyi başarıp başaramayacakları değildir. Bu yüzden modernist çabaları şundan dolayı sık sık hükümsüz kalmaktadır. Onlar sorunda her yönüyle düşünsel gerçeklerle yüzleşmeyip sorunun etrafını dolaşmaya çalışmakta ve yüzeysel bir kılıfa dayamak zorunda kalmaktadır. ${ }^{60}$

Diğer yandan Modern Türkiye'de problemin çözümü üzerine geliştirilen düşünceler Türk modernizminin sacayağını belirlemeye çalışırken Türk toplumu büyük bir değişim çemberinin içinde hızla yol alıyordu. Türk toplumu, Topçu'nun ifadelerine göre makineleşmiş Avrupa insanına benzeyen ruhsuz bir toplum olma eşiğine gelmişti. Nurettin Topçu'ya göre bunun nedeni, Gökalp modernleşmesini temsil eden görüşün düştüğü büyük hataydı. Zira Gökalp, dini kurumsal alandan soyutlayarak onu manevi alanın içine hapsetmek istiyordu. ${ }^{61}$ Böylece bir yandan dinle devletin arasını bulmaya çalışırken diğer yandan açılan teknik ihtiyacı karşılamak için batıdan ithal etmek yolunu öneriyordu. Ona göre bizim Türklük ve Müslümanlığ1mızı muhafaza etmek kaydıyla batı medeniyetine girmemizde bir sakınca yoktu. ${ }^{62}$ Ve İslam dini özünde getirdiği dinamikler sayesinde yeni medeniyet tarzına ayak uydurmamızı kolaylaştıracaktı. ${ }^{63}$

57 Aktay, “Modernleşme Ve Gelenek Bağlamında Dini Bilgi ve Otoritenin Dönüşümü", s. 140142

58 Buna benzer bir sınıflama Gökalp'te de vardır. Bkz. Gökalp, Türkleşmek, İslamlaşmak, Çağdaşlaşmak, s. 34-38

59 Fazlurrahman, İslam ve Çağdaşlık, çev. Alpaslan Açıkgenç, M. Hayri Kırbaşoğlu, Ankara: Fecr Yay., 1990, s. 266

60 Fazlurrahman, İslami Yenilenme, (Makaleler:3), s.56

61 Kılıç, Ziya Gökalp'in Din Sosyolojisi, s. 167

62 Kılıç, Ziya Gökalp'in Din Sosyolojisi, s. 79-80

63 Kılıç, Ziya Gökalp'in Din Sosyolojisi, s. 168

İslam dininin yeni örgütlenmelere ayak uydurabileceğine dair benzer bir düşünce Wach'da da vardır. Ona göre İslam'ın teolojik normları ve ahlaki kuralları sıkı ve gayet güzel tespit edilmişlerdi. Bununla birlikte fiiliyatta İslamiyet çevrelerin ve şartların bütün bir çeşitliliğine adapte alabileceğini ispat etmiş̧ir. Bkz. Wach, Din Sosyolojisi, s. 297

Celaleddin Çelik de Kuran'da toplumsal değişimi inceleyen çalışmasında benzer sonuçlara ulaştığını belirtmiştir. Ona göre mesela, er-Rad 13/11. Ayette hem toplum hem de bireyin karşılıklı değişebilirlik dinamikleri olduğu gösterilmiştir. Celaladdin Çelik, Kuran'da Toplumsal Değişim, İstanbul: İnsan Yay., 1996, s. 8 
Topçu, Gökalp'in modernleşmeci yaklaşımını radikal bir şekilde eleştirmiştir. Gökalp, Topçu'ya göre toplumsal gelişimin nesnel gerçekliğini kavrayamamış ve bu yüzden de "sosyolojik bir hataya düşmüştür. Topçu'ya göre biz batının iki yüzünü (ilim ve ahlak) tersinden gördük. Batılılaşmak isterken onun ilmini alıp ahlakını almamaya karar verdik. Ama ilimle ahlakın aynı kökten çıktığını bilemedik. Bu yüzden "batının tekniğini alalım ancak ahlakını almayalım" düşüncesi âdi ve âmiyâne bir müşahededir. Topçu, ahlakla tekniği birbirinden ayırmamaktadır. Onun düşüncesi en saf anlamda teknoloji düşmanı düşüncelerdir. Tekniğin gücü, ahlak ilahilerini susturan makine gıcırtılarıyla her tarafı doldurmuş ve dünyayı makineleştirmiştir. Makinelerin dizginleri elimizde olmasına rağmen şaha kalkan atlar bizi de sürüklemeye başlamıştır. Nurettin Topçu batıdan devşirilmiş bir teknoloji yerine kendi kültürümüze münasip bir teknik ihdas etmek gerektiğini belirtmiştir. İdeal ölçüleriyle yeniden kurulamayacak kadar bozulmuş olan Anadolu hiç değilse ideal geçmişinden yola çıkılarak ona benzetilmeye çalışılarak yeniden kurulabilir. Topçu "kültür medeniyeti durdurmalıdır" derken savunmacı bir konumdadır. Problem çağın problemidir. Dolayısıyla çağa özgü koşullarda tarzlarda ama eskiyi de gözeterek çözülmek zorundadır. ${ }^{64}$ Topçu devamla, geldiğimiz duruma bir nevi acıyarak bakmaktadır. Ona göre batı taklitçiliğimizle biz sadece başkasının yetiştirdiği ağaçtan meyve topladık. Ağaç yetiştirme zevkini yaşayamadık. Neslimizi yabancıların yetiştirmesine gelişme adına göz yumduk. Ortaya öksürüklü çelimsiz bir nesil çıktı. Bunun nedeni kendi medeniyetimizi tam yıktıktan sonra batı tekniğini kopya etmiş olmamızdır. Bunun çözümü ise şudur, teknik kendi medeniyetimizde çıkmış olmalıdır. Bu tabiatın zaruretidir. ${ }^{65}$

Erol Güngör İslam'ın bu günkü meselelerini incelediği çalışmasında, İslam'ın batı medeniyeti karşısındaki durumunu tahlil edenlerin çok defa Toynbee'nin "İslam, Batı ve İstikbal" adlı eserinde yer alan bir tasniften hareket ettiklerini söyler. Buna göre Toynbee, batının ezici tesiri karşısında İslam dünyasının kendi içinde iki tipin doğuşuna tanık olduğunu belirtir. Bunlardan biri "zealot" denilen tiptir ki, dış baskı karşısında bir çeşit arkaizme sığınır. Kendi medeniyetinin üstünlüğünü iddia ederek değişmeye direnir ve bu medeniyetin geçmişteki başarılarıyla övünür. Diğeri “ herodian" tiptir ki bunlar benzer baskılar altında kozmopolit bir tavır takınır. Kendi eski medeniyetini büsbütün bir kenara bırakır. ${ }^{66}$ Birinciler geleneği kurum, kural ve şekilleriyle aynen korumaya çalışırken ikinciler geleneğin

64 Süleyman Seyfi Ögün, Türkiye'de Cemaatçi Milliyetçilik ve Nurettin Topçu, İstanbul: Dergah Yay., 1992, s. 110-115

65 Nurettin Topçu, Kültür ve Medeniyet, İstanbul: Dergah Yay., 2004, s. 20

66 Güngör, İslam'ın Bu Günkü Meseleleri, s.192 
tüm unsurlarıyla tamamen miadını doldurduğuna ve yerini yeni yaşam tarzına bırakması gerektiğine inanıyorlar. Yeni yaşam tarzının en belirgin özelliği ise ilahi olandan uzak, alabildiğine dünyevileşmiş bir insan üretme çabasıydı. Ancak, daha önce de geçtiği gibi, modernizmin bütün çabalarına rağmen aşkın güç fikrinin ölmediğini, "eski"nin başat figürü "kutsal” ın yenidünyada da kendine yer edinmeyi başardığı açıktır.

Erol Güngör'ü kültürü ve medeniyeti koruma ve ancak teknik gelişmeleri de takip etme üzerine geliştirdiği düşünceleri ile Topçu'ya benzetebiliriz. Ancak Güngör konuyu biraz daha ileri seviyeye taşıyarak birkaç adım ötesini hesaplamak istemektedir. Ona göre Türkiye' de artık dinin eskiyi ve yeniyi temsil ettiği düşüncesi yıkılmış bulunuyor. Bu yüzden dindarlar veya İslamcılar eski-yeni konusunda kendilerini müdafaa etmekten ve dinin modernleşmeye engel olmadığını anlatmak durumundan çoktan kurtulmuşlardır. Şimdi ise alışılmışın dışında bir eski yeni kavgası başlamıştır. Bir taraftan eğitim nimetinden istifade ederek çağımızın problemleriyle başa çıkabilecek şekilde yetişmiş bir din adamı kadrosu, diğer yandan durgun ve reaksiyoner bir din anlayışını temsil eden bir başka kadro görüyoruz. Bunların ikisi de Türk halkının manevi liderliğini üstlenmek iddiasıyla yarışmaktadırlar. Ancak görünen o ki Türkiye'de İslam anlayışı, daha ziyade birinci grubun temsil ettiği çizgi etrafında şekillenecek ve istikbal şimdi azınlık olan bu küçük grubun elinde olacaktır. ${ }^{67}$

Bu haliyle Güngör'e göre aslında "nasıl değişmeliyiz" süreci belli ölçüde tamamlanmış, sürecin başına kimin geçeceği mücadelesi başlamıştır. Güngör kendi düşünce sistemi içinde eğitim nimetiyle çağın problemlerini kendi içerisinde yenecek potansiyeli yakalayan gruba sempatiyle bakarken gelecekle ilgili öngörülerini de bu grubun zaferi üzerinde yoğunlaştırmaktadır. Güngör'ün bu duruşunun günümüz aktüalitesinin içerisine değişik söylemlerle uzandığını görmek mümkündür. Nitekim Mustafa Armağan "gelenek ve modernlik arasında" adlı çalışmasında tartışmayı bir eskiler (ancients) yeniler (modernes) çekişmesinden çekip çıkarmak ve modern çağı da kapsayan daha genel daha kapsayıcı evrensel bir düzleme taşımak zorunlu olduğuna dikkat çekmiştir. ${ }^{68}$ Armağan, çözüm önerisini ise manevi değerleri anlamlı şekilde birleştirme üzerine kurgulamaktadır. Ona göre modernizmin sanat ve ahlakı birbirinden ayrıştıran, toplumu göz ardı eden yaklaşımını aşmamız gerekiyor. Ahlak, sanat ve bilimi yeniden ilişkilendirebilecek yeni bir çabaya ihtiyaç var. Modern dünyada sanat bilim ve ahlakı birleştirici bir fonksiyon üstlenen din ortadan kalkınca zamanla bu disiplinler de

67 Erol Güngör, İslam'ın Bu Günkü Meseleleri, İstanbul: Ötüken Neşriyat, 2006, s. 186-187

68 Armağan, Gelenek ve Modernlik Arasında, s. 63 
bağımsız birimler halinde kendi başlarına kaldılar. Her biri kendi alanında uzmanlaşmaya başladı. Bu disiplinlerin ürettiği malzemeleri topluma taşıyan gelenek kaybolunca ise toplumda uzaklaşan bir sanat "sanat, sanat içindir" anlayışı gelişti. ${ }^{69}$

Ali Bulaç ise Mustafa Armağan'ın dinin anlam ve değerleri birleştirici fonksiyonunu önceleyen tutumuna Kur'anî vahyi temel alan ve buna etnik farkları da katarak evrenselleştirmeyi öngören yaklaşımını ekleyerek düşünce evrenini genişletmeye çalışmıştır. Bulaç’a göre insanoğlunun büyük bir çevrimi tamamlamak üzere olduğu ve bunun belirtisi olarak derin bir krizden geçtiği zamanın bu evresinde İran Şiilği, Türk Sufiliği veya Arap Selefiliği bütün insanlara seslenen ilahi öğretinin tek ifade formu olamaz. Bunların her biri İslam mirasının bir mecrasıdır ama tek mecrası ve bütünü değildir. Bunlara tarihsel mirası ve geleneği oluşturması açısından karşı çıkılmaz ama tarih de gelenek de aşılmak durumundadır. Günümüzün Müslüman ulema ve aydını Kur'ani vahyi temel alarak kendi geleneğini doğrulamak, yabancı unsur ve çürümelerden temizlemek ve böylelikle ona kendisi de katkılarda bulunup sonraki kuşaklara aktarmak zorundadır. Müslümanlar bu yakın planda sergilenen manipülasyonları "son ilahi" mesajı derin kültürel ve entelektüel boyutlarda ve evrensel sorunları göz önüne alarak anlatmak suretiyle aşabilirler. ${ }^{70}$

\section{Sonuç}

Modernizmin yeni yaşam tarzı adına profan yaşamı önceleyen bir dünyayı önermesi onu doğal olarak başta İslam olmak üzere dinler ve geleneklerle çatışma ortamına soktu. Geleneksel islami düşünce ilk olarak modernizme karşı direnmeye başladı. Ancak zamanla bu direnişin her şeyi koşulsuz reddetmek ve geleneksel değerlerin her şeye yeteceğini düşünmekle ile zafere ulaşamayacağı anlaşıldı. Diğer yandan eskiye ait her şeyi büsbütün bırakmak da çözüm olmayacaktı. Öyleyse yeni bir formül gerekiyordu. Böylece hem eski değerleri dişlamayan hem de yeni değerleri içselleyebilen yeni formül arayışları başladı. Biz buna batı modernizmi karşısında birinci İslami aydinlanma diyebiliriz.

Aydınlanmanın ilk durağı modernizmin aslında "batılılaştırma" olma ihtimali oldu. Bu ihtimale göre aslında batı emperyalizmi modernleşme adı altında sinsice ve şeytani bir tarzda empoze edilmeye başlanmıştı. Bu bağlamda son dönem müslüman dünyasında modernliğe verilen en sert tepkilerden birinin "batılılaştırma" gayreti olduğu söylenebilir. Başta ilk sosyo-

69 Armağan, Gelenek ve Modernlik Arasında, s. 57-61

70 Bulaç, Din ve Modernizm, s. 221-225 
logların ve bazı oryantalistlerin doğuyu durağan batıyı ise dinamik olarak tanımlama çabaları bazı müslüman aydınların "batılılaşmanın sistematik olarak dayatıldı̆̆ı" şeklinde tepkisini çekmiştir. Bu tepki koşulsuz batılılaşma eğilimine yeni bir hedef belirlemiştir. İkinci durak ise aynı zamanda bu hedefin yönünü belirleyen "öyleyse batılılaşmadan nasıl modernleşe biliriz" aşamasıdır.

Dini geleneğin modern bir mefhum olarak dahi olsa yaşaması için verilen savaşım 1950'li yıllarda yine batıda kullanılmaya başlayan bir kavramla yeni bir boyut kazandı. Adına postmodernizm denilen bu kavram eski değerlere ve kutsal fikrine yeniden göz atmayı öneren bir düşünce platformunda gelişmeye başladı. Bu gelişme derhal müslüman aydınların düşünsel alanlarını gelenek-modernizm tartışmasından postmodernizm üzerine kaydırdı. Modernizm ve gelenek arasında sıkışan İslamî düşüncede ümitler postmodernizmin geleneği de kurtaracak bir can simidi olduğu üzerinde tekrar dirilmeye başladı. Ancak postmodernizmin, geleneğin formunu korumayı önerse de içeriğinde radikal değişikler yapmayı öngören tutumu İslamî düşüncenin değişmez naslara dayanan bazı hükümleriyle çatışmaya giriyordu. Modernizmin kökten değiştirmeci ve zorlayıcı tutumuna karşı bile direnmekten vaz geçmeyen İslamî düşünce geleneğinin buna hemen "evet" demesi beklenemezdi. Gelinen bu aşamada batılı olmayan ülkelerin kendi dinamikleri ile kendilerine özgü modernleşme tipi üretecekleri fikrini doğurdu. Buna göre İslam toplumları kendi gelenek ve kutsal değerlerine göre kendilerine özgü bir modernite geliştirebilirlerdi.

Dini geleneğin modern dünyada yaşatılması konusunda gelenekle ilgili düşüncelerin iki ana başlıkta toplandığını söyleyebiliriz. Birincisi eski yaşam tarzının zorunlu bir sonucu olarak ortaya çıkan kurallar, şekiller, kurumlar vs. gelenek olarak adlandırılır. Bunlar zamana göre değişiklik gösterebilir. İkincisi ise manevî değerler ve fikrî kaideler anlamında medeniyetlere ilham veren dinamik gelenektir. Gökalp birincisine kural, ikincisine ise gelenek adını vermiştir. Nasr’ın temsil ettiği gelenekçi düşünce ekolünü birinci grup geleneği önceleyen tutuma örnek verebiliriz. Bu ekole göre bizler tarihte gelenek adına ne yaşandıysa aynen yaşamaya ve modern zamanda tekrar canlandırmaya çalışmalıyız. Böylece karşılaştığımız problemleri "müteal" ilkelerden yararlanarak kolayca çözebiliriz. Bu ilkeler geçmişte problemlerimizi nasıl çözdüyse günümüzde de çözebilir. İkinci grup geleneği önceleyenlere ise Fazlurrahman çizgisinde hareket eden ekolü örnek verebiliriz. Bu ekole göre ise bizler İslam'ın temel kaynaklarını aslında modern zamanın bütün getirilerine anlamlı şekilde uyarlayabiliriz. Kuran ve Sünnet aslında her dönemin ruhuna en uygun olan hükmü seçmemizi önerir. Günümüzde de -mesela ceza hukukunda- yaşadığımız dünyanın ruhuna en uygun hü- 
kümleri seçebiliriz. Bu şekilde davranmakla Kuran'ın ruhuna aykırı düşmüş olmayı.

Modern Türkiye' de geliştirilen düşünce tarzında ise her ne kadar Fazlurrahman veya Nasr çizgisini aynen sürdürmek isteyenler olsa da burada gelişen hakim düşünce tarzının oldukça farklı olduğunu söyleyebiliriz. Bu düşünceye göre biz, bir yandan gelenekten fikir anlamında yararlanarak modern çağa ayak uydururken diğer yandan İslam'ın öz kaynaklarını aynen koruyabilir ve referans alabiliriz. Bu düşünce tarzının içinde bir birleştirme eğilimin olduğunu da söyleyebiliriz. Yani bu süreçte sadece Türk, İran veya Arap düşünce endeksli üretilen çözümler yeterli değildir. Müslümanlar bu yakın planda bir nevi mecbur bırakıldıkları değişim sürecini "son ilahi" mesajı derin kültürel bağlarından koparmadan evrensel sorunları göz önüne alarak anlatmak suretiyle aşabilirler.

\section{Kaynakça}

Akgül, Mehmet, "Modernleşme Çağında İslam Dünyasının Değişim Süreci ve Din Alanında Yaşanan Kırılma", Makalat, 1999/1.

Aktay, Yasin, "Modernleşme ve Gelenek Bağlamında Dini Bilgi Ve Otoritenin Dönüşümü", Bilimname VI, 2004/3, (131-151).

Armağan, Mustafa, Gelenek ve Modernlik Arasında, İstanbul: İnsan Yay., 1995.

Authwaite, William (Edit.), Modern Toplumsal Düşünce Sözlüğ̈̈, Haz. Melih Pekdemir, İstanbul: İletişim Yay., 2008.

Bulaç, Ali, Din ve Modernizm, İstanbul: Yeni Akademi Yay., 2006.

Cebeci, Suat "Din Eğitim Açısından Dinî Yaşantıların Gelenekleştirilmesi", Harran Üniversitesi İlahiyat Fakültesi Dergisi, Sayı:2, 1996.

Çapçığlu, İhsan, Küreselleşme Kültür ve Din, Ankara: Otto Yay., 2011.

Çelik, Celaladdin, Kuran'da Toplumsal Değişim, İstanbul: İnsan Yay., 1996.

Durkheim, Emile, Dini Hayatın İlkel Şekilleri, çev. Fuat Aydın, İstanbul: Ataç Yay, 2005.

Fazlurrahman, İslam ve Çă̆gdaşlık, çev. Alpaslan Açıkgenç, M. Hayri Kırbaşoğlu, Ankara: Fecr Yay., 1990.

Fazlurrahman, İslami Yenilenme, (Makaleler:3), çev. Adil Çiftçi, Ankara: Ankara Okulu Yay., 2002.

Gökalp, Ziya Türkleşmek, İslamlaşmak, Çağdaşlaşmak ve Doğru Yol, Haz. Yusuf Çotuksöken, İstanbul: İnkılap ve Aka Yay., 1976.

Görmez, Mehmet, "Bir Şeyler Yaparken Bütün Dünyayı Hesaba Katmalıyız”, Zaman:09.01.2012.

Güngör, Erol, İslam'ın Bugünkü Meseleleri, İstanbul: Ötüken Neşriyat, 2006.

Kağıtçıbaşı, Çiğdem, İnsan ve İnsanlar, İstanbul: Beta Basım Yayım, 1985.

Kılıç, Ahmet Faruk, Ziya Gökalp'in Din Sosyolojisi, İstanbul: Değişim Yay., 2008.

Kongar, Emre, Toplumsal Değişme, Ankara: Bilgi Yay., 1972.

Le Bon, Gustave, Kitleler Psikolojisi, İstanbul: Siyaset Hayat Yayınları, 1997.

Marshall, Gordon, Sosyoloji Sözlüğ̈̈, çev. Osman Akınbay, Derya Kömürcü, Ankara: Bilim Ve Sanat Yay., 1999. 
Meriç, Nevin, Değişen Kentte Dini Hayat, İstanbul: Kapı Yay., 2005.

Nasr, Seyyid Hüseyin, Makaleler:1, çev. Şehabeddin Yalçın, İstanbul: İnsan Yay., 1995.

Nortbourne, Lort, Modern Dünyada Din, çev. Şehabettin Yalçın, İstanbul: İnsan Yay., 1995.

Ögün, Süleyman Seyfi, Türkiye'de Cemaatçi Milliyetçilik ve Nurettin Topçu, İstanbul: Dergah Yay., 1992.

Öğüt, Salim Modern Düşüncenin Kur'an Anlayışı, İstanbul: Nun Yay., 2008.

Özay, Mehmet, Sekülerleşme ve Din, İstanbul: İz Yay., 2007.

Sirvani, Latif Ahmed, İkbal'in Konuşma Ve Yazıları, Çev. Can Ceylan, İstanbul: İnkılap Yay., 2011.

Sunar, Lütfi, Marx ve Weber'de Doğu Toplumları, İstanbul: Ayrıntı Yay, 2012.

Şeriati, Ali, Dine Karşı Din, çev. Hüseyin Hatemi, İstanbul: İşaret yay., 1987.

Medeniyet ve Modernizm, çev. Ahmet Yüksekoğlu, İstanbul: Bir Yay., 1985.

Taplamacıoğlu, Mehmet, Din Sosyolojisi, Ankara: Ankara Üniversitesi İlahiyat Fakültesi Yay., 1961

Topçu, Nurettin, Kültür ve Medeniyet, İstanbul: Dergah Yay., 2004.

Uludağ, Süleyman, İslam Düşüncesinin Yapısı (Selef, Kelam, Tasavvuf, Felsefe), İstanbul: Dergah Yayınları, 2010.

Ülken, Hilmi Ziya, Sosyoloji Sözlüğ̈ü, İstanbul: MEB Talim ve Terbiye Dairesi Yay, 1969.

Wach, Joachim, Din Sosyolojisine Giriş, çev. Battal İnandı, Ankara: Ankara Üniv. İlh. Fak. Yay., 1987. 